\title{
Detection of geminiviruses from tropical countries by a double monoclonal antibody ELISA using antibodies to African cassava mosaic virus
}

\author{
L Givord ${ }^{1 *}$, D Fargette ${ }^{2}$, B Kounounguissa ${ }^{3}$, JC Thouvenel 4, \\ B Walter ${ }^{3}$, MHV Van Regenmortel 1
}

1 Immunochimie, Institut de Biologie Moléculaire et Cellulaire du CNRS (IBMC), 15, rue René-Descartes, F67084 Strasbourg cedex ; 2 LPRC-ORSTOM, CIRAD, BP 5035, F34032 Montpellier cedex ;

3 INRA, BP 507, F68021 Colmar, France;

4 ORSTOM, 13, midan Ibn Afan, Dokki Cairo, Egypte

(Received 7 December 1993; accepted 6 May 1994)

\begin{abstract}
Summary - Using double antibody sandwich enzyme-linked immunosorbent assay (DAS-ELISA) tests, monoclonal antibodies (mAbs), which were prepared against particles of a Nigerian isolate of African cassava mosaic virus (ACMV), differentiated African geminiviruses (tomato yellow leaf curl virus, TYLCV; ACMV from West and East Africa; and okra leaf curl virus) from those originating in other countries of the world (euphorbia mosaic virus; Indian cassava mosaic virus; and TYLCV (Indian isolate)). All these viruses belong to the whitefly-transmitted geminivirus subgroup III. One $\mathrm{mAb}$ reacted with all 7 tested viruses and isolates. For detecting TYLCV from Senegal, it proved necessary to use a reducing agent in extraction buffer. A diagnostic DAS-ELISA was developed. This relies only on the use of mAbs and is useful for large-scale field screening.
\end{abstract}

geminivirus III / monoclonal antibody / ELISA / African cassava mosaic virus / tomato yellow leaf curl virus

Résumé - Détection de geminivirus de pays tropicaux par DAS-ELISA utilisant des anticorps dirigés contre le virus de la mosaïque africaine du manioc. Des anticorps monoclonaux (ACMC) dirigés contre le virus de la mosaique africaine du manioc ("ACMV») (isolat du Nigéria) et utilisés dans un test DAS-ELISA ("double antibody sandwich-ELISA") permettent de distinguer (à l'intérieur du sous-groupe III des geminivirus), les geminivirus originaires d'Afrique (ACMV souche Ouest et Est ; virus de l'enroulement jaunissant de la tomate : "TYLCV"; virus de l'enroulement du gombo) de ceux provenant des autres continents du monde (virus de la mosaíque de l'euphorbe ; virus indien de la mosaique du manioc; TYLCV de l'Inde). L'un de ces ACMc réagit avec les 7 geminivirus testés. Néanmoins, la détection du TYLCV (isolat du Sénégal) nécessite un tampon d'extraction spécifique, contenant un agent réducteur. Un test de diagnostic ou de détection utilisant seulement des AcMc, et par conséquent applicable à grande échelle, a été mis au point.

geminivirus III / anticorps monoclonaux / ELISA / virus de la mosaïque africaine du manioc / virus de l'enroulement jaunissant de la tomate

\footnotetext{
* Correspondence and reprints.
} 


\section{INTRODUCTION}

Cassava mosaic disease (Warburg, 1894) is the most important factor limiting cassava yields in many parts of Africa (Storey and Nichols, 1938) and can be observed almost everywhere on the continent where cassava is grown (Fauquet and Fargette, 1990). The causal agent is transmitted by the whitefly Bemisia tabaci (Kufferath and Ghesquière, 1932) and is maintained and carried to new areas in vegetatively propagated planting material (stem cuttings). Cassava mosaic is caused by a geminivirus (Bock and Woods, 1983) first isolated in Kenya under the name cassava latent virus (Harrison et al, 1977; Bock et al, 1978 ) and since renamed African cassava mosaic virus (ACMV; Bock and Woods, 1983). It has been detected in Côte d'Ivoire (Walter, 1980), Angola (Sequeira and Harrison, 1982), Nigeria (Adejare and Coutts, 1982) and several other African countries (Harrison and Robinson, 1988; Harrison et al, 1991a).

ACMV can be transmitted by inoculation of sap from cassava to Nicotiana benthamiana and can be detected by immunosorbent electron microscopy (Sequeira and Harrison, 1982), enzyme-linked immunosorbent assay (ELISA) (Sequeira and Harrison, 1982; Fargette et al, 1987) with polyclonal antibodies, and by hybridisation tests with CDNA probes (Roberts et al, 1984; Robinson et al, 1984). ACMV is placed in the geminivirus subgroup III, whose members have bipartite genomes and whitefly vectors (Francki et al, 1991) and are typically serologically related to one another (Roberts et al, 1984). These relationships reflect the degree of amino-acid sequence identity (about $70 \%$ or more) among the coat proteins of different members (Hamilton et al, 1984; Howarth et al, 1985).

Among whitefly-transmitted geminiviruses, the particles of ACMV (Thomas et al, 1986), Indian cassava mosaic (ICMV; Aiton and Harrison, 1989) and okra leaf curl (OLCV; Swanson and Harrison, 1993) viruses have been used to raise monoclonal antibodies (mAbs). In tests with a panel of 17 mAbs to ACMV (Harrison and Robinson, 1988; Harrison et al, 1991a) virus isolates from cassava fell into 3 groups on the basis of their patterns of reactions. These groups had different geographical distributions: group A (Africa, west of the Rift Valley), group B (Africa, east of the Rift Valley), and group C (ICMV; Indian subcontinent). Several of the mAbs to ACMV and ICMV reacted with other whitefly-transmitted geminiviruses infecting a wide range of crop and weed species in many countries in Africa, the Americas, Asia and Europe (Thomas et al, 1986; Harrison et al, 1991b; Muniyappa et al, 1991; Macintosh et al, 1992; Swanson et al, 1992a, 1992b). Some of the mAbs, in various combinations, were useful for detecting and identifying individual viruses, and others such as SCR20 detected nearly all the viruses.

The mAbs of Thomas et al (1986) were prepared to ACMV-Jl, an isolate derived by Stanley (1983) from the Kenyan type strain of ACMV. As the plant-breeding program for the improvement of cassava in West Africa necessitated a field test for the diagnosis, and hopefully, the eradication of ACMV, we prepared mAbs to ACMV isolate TMS 30211 from Nigeria. For routine detection of ACMV, a double antibody sandwich (DAS) ELISA relying only on the use of mAbs was developed.

\section{MATERIALS AND METHODS}

\section{Viruses}

The viruses were maintained at Scottish Crop Research Institute (SCRI, Dundee, UK) at $c a 25^{\circ} \mathrm{C}$ in an insect-proof glasshouse under licence from the Department of Agriculture and Fisheries for Scotland. The following hosts were used: $N$ benthamiana for ACMV from West Africa (Nigeria) (ACMV-W) and ICMV from India; Manihot esculentus for ACMV from East Africa (Malawi) (ACMV-E); Lycopersicon esculentum from tomato yellow leaf curl virus isolates from Senegal (TYLCV-S) and India (TYLCV-1); Abelmoschus esculentus for OLCV from Africa (Côte d'Ivoire); and $N$ benthamiana for euphorbia mosaic virus (EMV) from America (USA). ACMV-E was maintained in cuttings, TYLCV-S and TYLCV-I by grafting and OLCV by whitefly transmission.

At the INRA research station of Colmar (France) ACMV, isolate TMS 30211 (kindly provided by the International Institute for Tropical Agriculture, Ibadan, Nigeria) and other isolates of ACMV (Kounounguissa et al, 1989) were maintained in manually inoculated $N$ benthamiana in an insect-proof glasshouse under controlled conditions $\left(18-27^{\circ} \mathrm{C}, 16 \mathrm{~h}\right.$ light/day).

Particles of ACMV TMS 30211 were purified according to Kounounguissa et al (1989). The purified preparations were stored frozen at $-20^{\circ} \mathrm{C}$ after addition of $0.03 \% \mathrm{NaN}_{3}$. 


\section{Preparation of rabbit immunoglobulins}

The methods described by Kounounguissa et al (1989) were used to prepare rabbit immunoglobulins.

\section{Hybridoma production}

For the first fusion experiment, 3-6-week-old BALB/C and $B 10$ Brown mice were immunized by 3 intraperitoneal injections of ACMV (TMS 30211 virus isolate). Each animals was injected with $75 \mu \mathrm{g}$ purified virus for the 2 first injections and $100 \mu \mathrm{g}$ for the third one. The virus was emulsified with an equal volume of Freund's incomplete adjuvant for the first injection and complete adjuvant for the second and third injections. The mice were rested for 10 weeks, and then 2 mice (1 B10 Brown and $1 \mathrm{BALB} / \mathrm{c}$ ) were given 3 intraperitoneal booster injections with $50 \mu \mathrm{g}$ virus in saline each on days 5,4 and 3 before fusion. For the second fusion, 3-6-week-old BALB/c and B 10 Brown mice were immunized by 4 intraperitoneal injections at 2 weeks interval for the first 3 and then 1 month interval for the last injection (60, 45, 50 and $35 \mu \mathrm{g}$, respectively). Six weeks later, the mice were given 1 intravenous and 1 intraperitoneal booster injection of 34 and $80 \mu \mathrm{g}$ virus in saline, respectively. Three days after the second booster injection, the spleens were excised. Cell fusion was performed as described by Al Moudallal et al (1982) using the PAI myeloma cell line (Stocker et al, 1982). Selected positive cultures were cloned by limiting dilution, using $10^{7}$ thymocytes $/ \mathrm{ml}$ as feeder cells.

All clones were derived from BALB/c mice cells. The clones were multiplied in pristane-primed BALB/c mice by injection $0.5 \times 10^{7}$ hybridoma cells in $0.5 \mathrm{ml}$ Dulbecco's modified Eagle's medium into the peritoneal cavity. The ascitic fluid was harvested by tapping the peritoneum with a 19-gauge syringe needle, and the cells and debris were removed by centrifugation at $750 \mathrm{~g}$ for $30 \mathrm{~min}$ in a Jouan E96 centrifuge.

\section{Immunoassay used for screening hybridomas}

Wells containing growing hybridoma clones were screened for the presence of specific antibodies to ACMV TMS 30211 in both DAS and antigen-coated plates (ACP) indirect ELISA. In ACP-ELISA procedure the microtitre plates (Falcon, Oxnard, CA; Ref 3912) were coated with a purified preparation of ACMV $(0.35$ $\mu \mathrm{g} / \mathrm{ml}$ ) in $0.05 \mathrm{M}$ carbonate buffer $\mathrm{pH} 9.6$ (coating buffer) for $2 \mathrm{~h}$. The DAS-ELISA tests were carried out using rabbit IgG raised against $A C M V$ as a first antibody, at $1 \mu \mathrm{g} / \mathrm{ml}(2 \mathrm{~h})$, in coating buffer, followed by incubation with the antigen at $0.35 \mu \mathrm{g} / \mathrm{ml}$ in phosphatebuffered saline, $\mathrm{pH} 7.4$, containing $0.05 \%$ Tween 20 (PBS-T) overnight at $4^{\circ} \mathrm{C}$. The rabbit IgG used in this test has been described previously (Kounounguissa et al, 1989). In both methods the remaining binding sites on the plastic plates were then saturated by incubation with $1 \%$ bovine serum albumin (BSA) in PBS-T. PBS-T was used as the diluting buffer in the subsequent steps. Hybridoma culture supernatant fluids were diluted $1 / 3$ or $1 / 5$ and an alkaline phosphatase-conjugated affinipure sheep anti-mouse $\lg G(H+L)$ (Jackson ImmunoResearch Laboratories, West Grove, PA) diluted 1/3 000 was used as the detecting antibody. The bound conjugate was detected by addition of the substrate, $p$-Nitrophenylphosphate in $0.1 \mathrm{M}$ diethanolamine buffer $\mathrm{pH}$ 9.8. Optical density $(405 \mathrm{~nm})$ values were measured with a Titertek Multiskan photometer (Flow Laboratories). Absorbance values were considered positive if they exceeded that of the buffer control by a factor of 3 .

\section{Labelling of reagent}

For biotinylating mAbs, $\mathrm{N}$-hydroxysuccinimidobiotin (Sigma) (biotin) dissolved in distilled dimethylformamide $(0.2 \mathrm{mg} / \mathrm{ml})$ was added to mAbs (ascitic fluid) diluted at around $1.5 \mathrm{mg} / \mathrm{ml}$, in a $1: 5 \mathrm{biotin} / \mathrm{mAbs}$ ratio $(w / w)$; after incubating the mixture at $25^{\circ} \mathrm{C}$ for $2 \mathrm{~h}$, the reaction was stopped by addition of $1 \mathrm{M} \mathrm{NH}_{4} \mathrm{Cl}$ (Zrein et al, 1986). Alkaline phosphatase-conjugated streptavidin was from Jackson Immuno Research.

\section{Crude extract preparation}

Plant extracts prepared at SCRI were ground in mortar and pestle in $0.05 \mathrm{M}$ Tris/ $\mathrm{HCl}$ buffer, $\mathrm{pH} 8.0,2 \%$ polyvinylpyrrolidone (PVP), $0.5 \%$ Tween 20 (1 g tissue in $10 \mathrm{ml}$ buffer) containing $0.005 \mathrm{M}$ EDTA. A specific buffer for TYLCV was devised through ELISA tests by optimising successive steps including buffer ion, $\mathrm{pH}$, molarity and additives: $0.05 \mathrm{M} \mathrm{Tris} / \mathrm{HCl}, \mathrm{pH} 8.5,60 \mathrm{mM}$ sodium sulfite.

Extracts prepared at IBMC (Strasbourg, France) and the ORSTOM laboratory (Côte d'lvoire) were made with cassava tip leaves rapidly frozen in liquid nitrogen in a chilled mortar, and ground with PBS-T ( $1 \mathrm{~g}$ tissue to $3 \mathrm{ml}$ buffer) and sterilized quartz sand. The nitrogen step proved essential as otherwise no virus could be detected by ELISA test in the extract. For clarification, the crude extract was centrifuged at $3000 \mathrm{~g}$ for $20 \mathrm{~min}$ in Jouan E96 centrifuge.

\section{ELISA tests used for diagnosis}

MAbs were used in indirect DAS-ELISA (Procedure 1) as described in Muniyappa et al (1991). Microtiter plates were coated with $1 \mu \mathrm{g} / \mathrm{ml} \gamma$-globulin from polyclonal antiserum to ACMV-W; infectious sap was prepared as described above; bound viral antigen was exposed to diluted ascitic fluid at a concentration high enough to give a strong reaction with the homologous virus (dilution between $10^{-4}$ to $10^{-5}$ ), followed by $2 \mathrm{~h}$ incubation at room temperature with rabbit anti-mouse globulin alkaline phosphatase conjugate and substrate. 
Optical density (OD) readings (A $405 \mathrm{~nm}$ ) were taken after incubation with substrate for 1 or $2 \mathrm{~h}$ at room temperature and again after overnight incubation at $5^{\circ} \mathrm{C}$.

Procedure 2 corresponds to direct DAS-ELISA. The $\mathrm{mAb}$ was diluted (ascitic fluid dilution 1:1 000) in coating buffer and incubated in microtiter wells for $3 \mathrm{~h}$ at room temperature. The viral antigens (crude sap) were diluted in $0.05 \mathrm{M}$ Tris/ $\mathrm{HCl}$ buffer, at $\mathrm{pH} 8.02 \%$ PVP, $0.5 \%$ Tween containing $0.005 \mathrm{M}$ EDTA, and incubated over night at $5^{\circ} \mathrm{C}$. Biotinylated mAb (dilution 1:10 000) was used to detect captured antigen ( $2 \mathrm{~h}$ at room temperature) and was revealed using streptavidin conjugated to alkaline phosphatase, diluted 1:1 000 in PBST containing $1 \% \mathrm{BSA}$ and $2 \%$ PVP $(2 \mathrm{~h}$ at room temperature) following by the substrate $p$-nitrophenyl phosphate. As in Procedure 1, readings were taken after incubation with substrate for 1 or $2 \mathrm{~h}$ at room temperature and again after overnight incubation at $5^{\circ} \mathrm{C}$. The same mAb was used for coating the plate as second biotinylated antibody.

To detect ACMV in extracts from infected leaves of $N$ benthamiana, mAbs were used at various concentrations: ascitic fluids were diluted from $10^{-3}$ to $10^{-4}$ for $\mathrm{mAb} 7$ and from $5 \times 10^{-4}$ to $10^{-5}$ for $\mathrm{mAb} 11$.

\section{Immunoblotting}

Western blots tests were carried out as described by Harlow and Lane (1988). Samples of ACMV and TYLCV were extracted from infected leaves and mixed with sample buffer made of $60 \mathrm{mM}$ Tris/glycine, $2 \%$ SDS, $100 \mathrm{mM}$ dithiothreitol and $0.01 \%$ bromophenol blue.

\section{RESULTS}

\section{Characterisation of the mAbs}

Only one clone was obtained from the first fusion experiment, the mAb 41 , which reacts only in
ACP - ELISA with purified ACMV. Two clones were obtained from the second one, mAb 7 and mAb 11, which react in ACP and DAS - ELISA. Table I indicates the reactions obtained in indirect DAS-ELISA when mAbs 7 and 11 were tested against a range of well-characterised geminiviruses obtained from various geographical areas and various host plants (see list in Materials and methods). The pattern of reactions was different for the 2 antibodies. mAb 11 reacted strongly with all tested geminiviruses. By contrast, mAb 7 reacted only with geminiviruses from Africa.

In Western-blot tests, mAbs 7 and 11 gave no reaction with $A C M V$ in infected leaves of $N$ benthamiana.

\section{Immunoassays}

The results in table I were obtained with virus material extracted in PBS with $0.5 \%$ Tween-20 and $\%$ PVP, pH 7.5. In order to establish if other extraction buffers gave better results, leaves infected with TYLCV were extracted in various buffers. Results obtained in direct DAS-ELISA with $\mathrm{mAb} 11$ conjugated with biotin are shown in figure 1. Similar results were obtained in indirect DAS-ELISA. Low values were reached when standard buffers used for many viruses (Converse and Martin, 1990) and geminiviruses (Harrison et al, 1991b) were applied. A specific extraction buffer containing sodium sulfite (see Materials and methods) allowed much higher readings with TYLCV isolates from Senegal, Egypt, Nigeria, Burkina-Faso and Sicily. There was a linear relationship between OD $(405 \mathrm{~nm})$ values and the dilution of the extract (in a $\mathrm{log} / \mathrm{log}$ representation; regression coefficient $R^{2}=0.98$ ). This allowed titration and comparisons of virus concentration in leaf extracts.

Table I. Reaction strengths (OD $(405 \mathrm{~nm}))$ after overnight incubation with substrate $\left(4^{\circ} \mathrm{C}\right)$ in indirect DAS-ELISA test, with geminiviruses from various host plants and from different geographic origins (see list in Materials and methods) extracted in PBS with $0.5 \%$ Tween-20 and $2 \%$ PVP, $\mathrm{pH} 7.5$.

\begin{tabular}{lccccccc} 
Antibody & \multicolumn{9}{c}{ Virus } \\
\cline { 2 - 6 } & ACMV-W & ACMV-E & ICMV & TYLCV-S & TYLCV-I & OLCV & EMV \\
\hline mAb 7 & 3 & 3 & 0 & 1 & 0 & 3 & 0 \\
mAb 11 & 3 & 3 & 3 & 2 & 3 & 3 & 2 \\
\hline
\end{tabular}




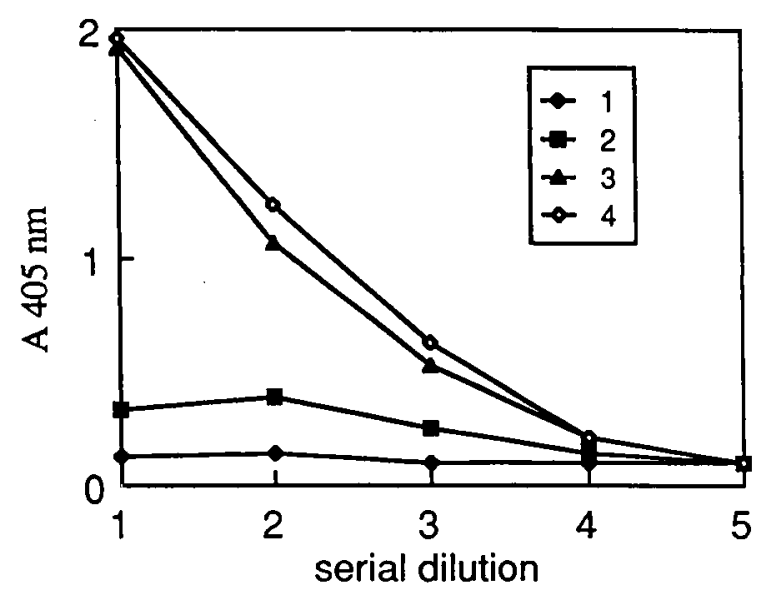

Fig 1. OD (405 nm) values in direct DAS-ELISA test with mab 11 (see Materials and methods) for a 5-fold dilution series of TYLCV-S-containing sap extracted in: (- -) PBS with $0.5 \%$ Tween-20 and $2 \%$ PVP, pH $7.5 ;(--) 0.05 \mathrm{M}$ Tris/ $\mathrm{HCl}, 0.005 \mathrm{M}$ EDTA, pH 8.0, 2\% PVP and $0.5 \%$ Tween; $(-\mathbf{A}-) 0.05 \mathrm{M} \mathrm{Tris} / \mathrm{HCl}, \mathrm{pH} 8.5,60 \mathrm{mM}$ sodium sulfite; $(-\diamond-)$ as for $(3)+1 \%$ mercaptoethanol.

When mAb 11 was conjugated with biotin and used in direct DAS-ELISA (see Materials and methods), ACMV-W was readily detected at dilutions of 1:1 000 and TYLCV-S up to 1:25 of the crude extracts (table II). However, the sensitivity of direct DAS-ELISA tests was lower than that of indirect DAS-ELISA tests, by a factor of 10 for ACMV and 1:25 for TYLCV. Coating the plates with mAbs gave values comparable and sometimes higher than those obtained when coating with polyclonal serum. For instance, in one set of experiments with TYLCV-containing extracts in direct DAS-ELISA, values were 1.65 with the mabs and 0.95 with the polyclonal antibodies, whereas background reactions with healthy sap were similar ( 0.12 and 0.13 , respectively). In both tests however, the background values were higher than those obtained in indirect DAS-ELISA (0.12 vs 0.07 ).

\section{Field tests}

Indirect DAS-ELISA using mAb 11 has been successfully used for screening cassava plants for the presence of ACMV. The ORSTOM field cassava collection in Côte d'Ivoire and the glasshouse collection at the INRA research station of Colmar, which include varieties from several countries, were both tested in this way. Fourty-one isolates were tested and yielded $O D$ (corrected for background) ranging from 0.6 to 2.8 (Côte d'Ivoire: 13 isolates; Kenya: 8; Nigeria: 8; South American Continent: 4; India: 3; Madagascar: 3; Togo: 1; Central African Republic: 1). This test has also been successfully used $(O D>1.5)$ with the sodium-sulfite-containing buffer to detect geminiviruses in tomato leaf samples from Senegal, Egypt, Nigeria, BurkinaFaso and Sicily, in laboratories located in these countries or in laboratories in Europe that had received samples from there. In Egypt, these mAbs have also been successfully used to assess the presence of a suspected whiteflytransmitted geminivirus in the ornamental plant Althea rosea (Malvaceae) which exhibited symptoms close to OLCV and which might be a natural reservoir of this virus.

Table II. OD (405 nm) values obtained in direct DAS-ELISA and indirect DAS-ELISA with ACMV-W and TYLCV-S extracts in a 10-fold dilution series for ACMV and 5-fold dilution series for TYLCV and mAb 11.

Virus

Serial dilution

\begin{tabular}{|c|c|c|c|c|c|}
\hline 1 & 2 & 3 & 4 & 5 & Healthy \\
\hline $1 / 1$ & $1 / 10$ & $1 / 100$ & $1 / 1000$ & $1 / 10000$ & \\
\hline$>2$ & $>2$ & $>2$ & $0.53^{\star}$ & 0.11 & 0.08 \\
\hline$>2$ & $>2$ & $>2$ & $>2$ & 0.51 & 0.06 \\
\hline $1 / 1$ & $1 / 5$ & $1 / 25$ & $1 / 125$ & $1 / 525$ & \\
\hline$>2$ & 1.32 & $0.48^{*}$ & 0.19 & 0.11 & 0.12 \\
\hline$>2$ & $>2$ & 1.74 & 0.61 & $0.17^{\star}$ & 0.07 \\
\hline
\end{tabular}

The first dilution (1/1) is the crude extract prepared as described in Materials and methods (1 $\mathrm{g}$ leaf in $10 \mathrm{ml}$ extraction buffer). ${ }^{*}$ Last dilution giving a reading more than twice the background reaction obtained with healthy sap. 


\section{DISCUSSION}

The ELISA results indicate that the 2 mAbs (11 and 7) that we have prepared with ACMV-W, recognize 2 different conformational epitopes, which are not preserved when the viral protein is denatured by treatment with SDS and dithiothreitol in Western blot tests. They also indicate that $\mathrm{mAb} 11$ is directed against an epitope shared by 7 viruses or isolates from various hosts and locations, whereas the epitope recognized by $\mathrm{mAb} 7$ is restricted to the 4 viruses or isolates from Africa. The contrasting patterns of reactions between the 2 mAbs suggest a geographical variation of the epitope profile, a feature already reported for other mAbs directed towards geminiviruses (Harrison and Robinson, 1988) and viruses from other groups (Matthews, 1990).

Any large epidemiological, sanitation or resistance program in a developing country implies a large number of tests and requires unrestricted access to inexpensive immunological reagents. Using monoclonal instead of polyclonal antibodies in the coating stages of the DAS-ELISA tests will overcome the difficulty linked to limited amounts of polyclonal antibodies. Direct DAS-ELISA using mAbs as captured antibodies and second biotinylated antibodies is sufficiently sensitive for the routine detection of ACMV and TYLCV. However, a more sensitive detection of the viruses can be achieved by indirect DAS-ELISA. The nature of the extraction buffer is also critical for optimal virus detection and must be adjusted for each geminivirus studied. For extracting TYLCV-S, for instance, it is necessary to use the reducing agent sodium sulfite, which presumably stabilizes the virus structure and maintains the antigenic reactivity in the ELISA test. Similar results have been described for tobacco leaf curl virus (Macintosh et al, 1992).

The 2 mAbs described in this article allowed the detection of whitefly-transmitted geminiviruses from various plants and from various geographical origins. They have also been successfully used to assess virus concentrations in plants and to search for natural reservoirs of the viruses. Furthermore, using mAb 11 in immunoblotting, one of us has recently detected geminiviruses in the following host plants in Egypt: tomato, okra, cucumber, Datura stramonium, Cucurbita pepo, and Althea rosea (Gosselin and Thouvenel, unpublished results). These results confirm the ability of mAbs 11 in the detection of geminiviruses in various plant species. However, these tests must be complemented by other information such as symptomatology, transmission and host range when full identification of the virus is needed.

\section{ACKNOWLEDGMENTS}

Part of this work was made during the stay of the second author at SCRI. Special thanks are due to BD Harrison for helpful discussions. This research was financed in part by a collaborative program of CNRS and ORSTOM.

\section{REFERENCES}

Aiton MM, Harrison BD (1989) Monoclonal antibodies to Indian cassava mosaic geminivirus (ICMV). Rep Scott Crop Res Inst 1988, 175

Al Moudallal Z, Briand JP, Van Regenmortel MHV (1982) Monoclonal antibodies as probes of the antigenic structure of tobacco mosaic virus. EMBO J1, 1005-1010

Adejare GO, Coutts RHA (1982) The isolation and characterisation of a virus from Nigerian cassava plants affected by the cassava mosaic disease and attempted transmission of the disease. Phytopathol Z 103, 198-210

Bock KR, Woods RD (1983) Etiology of African cassava mosaic disease. Plant Dis 67, 994-995

Bock KR, Guthrie EJ, Meredith G (1978) Distribution, host range, properties and purification of cassava latent virus, a geminivirus. Ann Appl Biol 90, 361367

Converse R, Martin R (1990) Enzyme-linked immunosorbent assay (ELISA). In: Serological Methods for Detection and Identification of Viral and Bacterial Plant Pathogens (R Hampton, E Ball, S de Boer, eds), APS Press, Saint Paul, MN, USA, 179196

Fargette D, Thouvenel JC, Fauquet C (1987) Virus content of leaves of cassava infected by African cassava mosaic virus. Ann Appl Biol 110, 65-73

Fauquet C, Fargette D (1990) African cassava mosaic virus: etiology, epidemiology, and control. Plant Dis 74, 404-411

Francki RIB, Fauquet C, Knudson DL, Brown F (1991) Classification and nomenclature of viruses; fifth report of the international committee on taxonomy of viruses. Arch Virol Suppl 2, 1-450

Hamilton WDO, Stein VE, Coutts RHA, Buck KW (1984) Complete nucleotide sequence of the infectious cloned DNA components of tomato golden mosaic virus: potential coding regions and regulatory sequences. EMBO J 3, 2197-2205

Harlow E, Lane D (1988) Antibodies. A Laboratory Manual. Cold Spring Harbor Laboratory, New York, $726 \mathrm{pp}$ 
Harrison BD, Robinson DJ (1988) Molecular variation in vector-borne plant viruses: epidemiological significance. Philos Trans $R$ Soc Lond B Biol Sci 321, 447-462

Harrison BD, Barker H, Bock KR, Guthrie EJ, Meredith G, Atkinson M (1977) Plant viruses with circular single-stranded DNA. Nature (Lond) 270 , 760-762

Harrison BD, Swanson MM, McGrath P', Fargette D (1991a) Patterns of antigenic variation in whiteflytransmitted geminiviruses. Annu Rep Scott Crop Res Inst 1990, 88-90

Harrison BD, Muniyappa V, Swanson MM, Roberts IM, Robinson DJ (1991b) Recognition and differentiation of seven whitefly-transmitted geminiviruses from India, and their relationships to African cassava mosaic and Thailand mung bean yellow mosaic viruses. Ann Appl Biol 118, 299-308

Howarth AJ, Caton J, Bossert M, Goodman RM (1985) Nucleotide sequence of bean golden mosaic virus and a model for gene regulation in geminiviruses. Proc Natl Acad Sci USA 82, 3572-3576

Kounounguissa BR, Givord L, Walter B (1989) African cassava mosaic virus (ACMV): stability of purified virus and improved conditions for its detection in cassava leaves by ELISA. J Phytopathol 127, 29 . 41

Kufferath $\mathrm{H}$, Ghesquière $\mathrm{J}(1932)$ La mosaïque du manioc. CR Soc Biol Belge 109, 1146-1148

Matthews REF (1990) Plant Virology. Third Edition. Academic Press, London

Macintosh S, Robinson DJ, Harrison BD (1992) Detection of three whitefly-transmitted geminiviruses occurring in Europe by tests with heterologous monoclonal antibodies. Ann Appl Biol 121, 297-303

Muniyappa V, Swanson MM, Duncan GH, Harrison BD (1991) Particle purification, properties and epitope variability of Indian tomato leaf curl geminivirus. Ann Appl Biol 118, 595-604

Roberts IM, Robinson DJ, Harrison BD (1984) Serological relationships and genome homologies among geminiviruses. J Gen Virol 65, 1723-1730
Robinson DJ, Harrison BD, Sequeira JC, Duncan GH (1984) Detection of strains of African cassava mosaic virus by nucleic acid hybridisation and some effects of temperature on their multiplication. Ann Appl Biol 105, 485-493

Sequeira JC, Harrison BD (1982) Serological studies on cassava latent virus. Ann Appl Biol 101, 33-42

Stanley J (1983) Infectivity of the cloned geminivirus genome requires sequences from both DNAs. Nature (Lond) 305, 643-645

Stocker JW, Foster HK, Miggiano $V$ et al (1982) Generation of two new myeloma cell lines "PAl" and "PAI-O" for hybridoma production. Res Disclos 217 , 155-157

Storey HH, Nichols RFW (1938) Studies of the mosaic disease of cassava. Ann Appl Biol 25, 790-806

Swanson MM, Harrison BD (1993) Serological relationships and epitope profiles of isolates of okra leaf curl geminivirus from Africa and the Middle East. Biochimie 75, 707-711

Swanson MM, Varma A, Muniyappa V, Harrison BD (1992a) Comparative epitope profiles of the particle proteins of whitefly-transmitted geminiviruses from nine crop legumes in India. Ann Appl Biol 120, 425433

Swanson MM, Brown JK, Poulos BT, Harrison BD (1992b) Genome affinities and epitope profiles of whitefly-transmitted geminiviruses from the Americas. Ann Appl Biol 121, 285-296

Thomas JE, Massalski PR, Harrison BD (1986) Production of monoclonal antibodies to African cassava mosaic virus and differences in their reactivity with other whitefly-transmitted geminiviruses. J Gen Virol 67, 2739-2748

Walter B (1980) Isolation and purification of a virus transmitted from mosaic-diseased cassava in the Ivory Coast. Plant Dis 64, 1040-1042

Warburg O (1894) Die Kulturpflanzen Usambaras. Mitt dtsch Schutzgeb 7, 131-198

Zrein M, Burckard J, Van Regenmortel MHV (1986) Use of the biotin-avidin system for detecting a broad range of serologically related plant viruses by ELISA. $J$ Virol Methods 13, 121-128 